New York, on I I-I 2 April 1969, bringing together State University faculties from various campuses and representatives of several New York State school districts.

Dr. Joseph E. Harris, Professor of African History at New Paltz, opened the conference with an introductory address. The themes of the several sessions of the two-day meeting included 'African studies in schools, colleges, and universities' and ' Racial prejudice, teaching, and learning: Africans and Afro-Americans'. Speakers included Professor Edward Soja, Northwestern University, Dr. Frances Bonner, Psychoanalyst, of Newton, Massachusetts, and Mr. Ray Giles, of the African-American Institute.

\title{
Symposium on the African Cultural Contribution in Latin America and the Carib- bean Area
}

Tris symposium was held in Havana from 17 to 21 December 1968, organized by UNESCO, the Cuban National Commission for UNESCO, and the Institute of Ethnology and Folklore of the Cuban Academy of Sciences. Some twenty specialists attended from Latin America, Europe, and Africa, among them Miguel Acosta-Saignes (Venezuela), Aguirre Beltrán (Mexico), Ildefonso Pereda-Valdés (Uruguay), Léon G. Damas (Guyana), Roger Bastide (France), José A. Portuondo, Director of the Cuban Institute of Literature and Linguistics, and Argeliers Léon, Director of the Cuban Institute of Ethnology and Folklore. Papers were delivered in the fields of cultural anthropology, musicology, literature, and history of thought. The principal subjects of the conference were related to the adaptation of the Afro-Latin-American to the Western cultures, the transmission of Afro-American culture and the creation of a new culture.

\section{(Communicated by Luis Beltrán)}

\section{The Institute for the Study of Man in Africa}

THE Institute's seventh annual Raymond Dart Lecture was delivered by Professor Monica Wilson of the University of Cape Town on 4 June 1969. The subject was 'The thousand years before Van Riebeeck : reflections on early peoples of South Africa'.

\section{La Participation des facultés et instituts europeéns au développement juridique africain}

L'Association internationale de Droit africain (International African Law Association) a tenu à Bruxelles, du 2 au 5 juillet 1969 , une réunion consacrée à la participation des facultés et instituts européens au développement juridique africain. Une trentaine de participants y représentaient des facultés ou instituts de recherche allemands, américains, anglais, belges, français, italiens et scandinaves, en même temps que des institutions internationales comme l'Institut international pour l'Unification du Droit privé (UNIDROIT); chacun d'entre eux avait présenté dans une brève note les réalisations et les projets de son institution dans le domaine du droit africain. Les discussions, présidées successivement par MM. les Professeurs Wengler (Berlin), Young (Northwestern), Costanzo (Pérouse), Allott (Londres) et Rubbens (Leuven) permirent, au cours des deux premières journées, d'examiner à la fois le bilan de l'oeuvre accomplie et les problèmes que posait l'avenir tant de la recherche que de l'enseignement du droit africain dans les facultés et instituts d'Europe. A cette occasion, l'accent fut fréquemment mis sur la nécessité d'une coordination des efforts européens. Aussi la dernière journée fut-elle consacrée à la mise en oeuvre de cette coopération européenne au service de l'Afrique. La conférence décida notamment de mettre en chantier la création d'un Centre européen de droit africain qui aurait notamment pour tâches de dresser un répertoire permanent des enseignants et chercheurs travaillant dans ce domaine scientifique, d'établir des contacts entre ceux-ci et les universités et gouvernements africains, 